\title{
CARBONATED BEVERAGES INDUCED HYPERCALCIURIA IN YOUNG MALES
}

\author{
Shamsul Arfeen Khan, Habibullah Qureshi, Mujtaba Farooq Rana, \\ Khemomal A. Karira and Hasan Ali
}

\begin{abstract}
OBJECTIVE: To assess the short-term effects of carbonated beverages on urinary calcium exertion in normal young males.

SETTING: Department of Biochemistry, Basic Medical Sciences Institute, Jinnah Postgraduate Medical Centre, Karachi, from July 2003 to June 2004.

METHOD: Twenty-five normal male subjects of 20-40 years age and habitual users of carbonated beverages were selected for the study. Their fasting and post-beverage urine samples were collected and analyzed for calcium excretion levels.

RESULTS: Significant increase in urinary calcium levels was observed in subjects consuming both caffeinated $(P<0.001)$ and non-caffeinated $(P<0.01)$ beverages.

CONCLUSION: The excess calciuria is confined to males who are habitual consumers of both caffeinated and non-caffeinated beverages. It is suggested that habitual use of beverages must be discouraged in order to prevent bone resorption and hence, an early osteoporosis.
\end{abstract}

KEY WORDS: Carbonated beverages. Habitual consumption. Hypercalciuria.

\section{INTRODUCTION}

Intake of carbonated beverages has been associated with reduced bone mass or increased fracture risk, both later in life ${ }^{1}$ and in children and adolescents. ${ }^{2}$ Colas were more strongly associated than other carbonated beverages. The factors responsible for this association may be an increase in phosphorus intake or the net acid load of the beverages that use phosphoric acid as the acidulant or the caffeine of those beverages that are caffeinated. Recently, fructose used in beverages as a natural sweetener, was implicated as a possible cause of reduced calcium balance. ${ }^{3}$

Low bone mineral density is due to genetic, hormonal or environmental factors, e.g. diet may be casually related to fractures. ${ }^{4}$ Calcium and its supplementation have been found to increase bone mineral density. ${ }^{5}$ Osteoporotic fractures may be affected by diet and activity among young women. ${ }^{6}$ The simplest example of an acid-ash food product is a cola drink. Since, bone is the largest source of Phosphate buffer in the body, it is likely to participate in the buffering of a cola drink, unless the diet provides adequate buffer. Study has evidence that an acid-ash diet causes excessive calcium loss and a negative calcium balance and that the ingestion of a carbonated buffer reverses this loss and improves the calcium balance. ${ }^{7}$ Change in lifestyle of urban population especially youngsters consuming more soft drinks both caffeinated and noncaffeinated regularly, appealed us to see their effects on calcium excretion so to avoid the harmful effects.

\section{SUBJECTS AND METHODS}

This study was carried out in the Department of Biochemistry at Basic Medical Sciences Institute (BMSI), Jinnah Postgraduate Medical Centre (JPMC), Karachi. Twenty-five male subjects of $20-40$ years age belonging to different areas of Karachi were studied. All the subjects were habitual users of carbonated beverages about $500 \mathrm{ml}$ daily. They were non-diabetic, normotensive, having no history of acute or chronic urological problem, or of renal stone formation. They were not on calcium therapy and were having no any gastrointestinal disorder. They were educated and briefed about the study protocol. Same protocol was, as reported in the previous study ${ }^{8}$ was followed. All the subjects were given a $500 \mathrm{ml}$ of deionized water on the day-1 of study as a negative control; a $500 \mathrm{ml}$ of carbonated beverage containing caffeine on day-2; a $500 \mathrm{ml}$ of carbonated beverage without caffeine on day-3; and a $500 \mathrm{ml}$ of milk ('EveryDay' milk of Nestle Consumer Services, 308 Upper Mall Lahore, 
Pakistan) on day- 4 of the study as a positive control. The subjects were asked to report after an overnight fasting, voiding their first morning urine sample and after further two hours fasting, their first fasting urine sample was collected. They were then given a breakfast of low calcium diet along with a $500 \mathrm{ml}$ of test drink each day. After a 5 hours pause (without taking any further diet) their urine samples were recollected as post-beverage samples. These samples were then analyzed for calcium levels by using a kit, Cat \# CA590 of Randox Company. The reducing sugars were performed through benedict's qualitative reagent to exclude the presence of reducing sugar. The beverages were also analyzed for the caffeine content and dissolved carbon-dioxide by method of Modern food analysis by Mart and Fisher, 1971 from the laboratory of Pakistan Council of Scientific and Industrial Research (PCSIR), Karachi while sodium ${ }^{9}$, phosphorus ${ }^{10}$, calcium by flame photometer, $\mathrm{pH}$ by $\mathrm{pH}$ meter, dried weight by Hot - Oven method and sugars by using chemical methods in the Biochemistry laboratory of BMSI, JPMC, Karachi. Comparison of the data for pre-beverage (fasting) and post-beverage samples was carried out by using the student's t-test.

\section{RESULTS}

The composition and characteristics of the beverages used in the study are shown in Table I. All the analyses were performed in the laboratory of Biochemistry department (BMSI) while caffeine content and dissolved $\mathrm{CO}_{2}$ were analyzed by the laboratory of PCSIR, Karachi on providing the beverage samples. Table II shows the comparison of urinary calcium levels for pre and post-drinks which found significant increase in caffeinated $(P<0.001)$ and non-caffeinated carbonated beverages $(P<0.01)$. Meanwhile deionized water showed significant decrease in urinary calcium levels $(P<0.001)$. The data of physiological parameters and anthropometrical measurements of study subjects are shown in Figure I.

TABLE I:

COMPOSITION AND CHARACTERISTICS ${ }^{1}$ OF BEVERAGES

\begin{tabular}{|c|c|c|c|c|c|c|c|c|}
\hline BEVERAGE & $\begin{array}{l}\text { CAFFEINE }{ }^{2} \\
(\mathrm{mg})\end{array}$ & $\begin{array}{l}\text { SODIUM }^{3} \\
(\mathrm{mEq})\end{array}$ & $\begin{array}{l}\text { PHOSPH- } \\
\text { OROUS }^{3} \\
(\mathrm{mmol})\end{array}$ & $\mathrm{pH}^{3}$ & $\begin{array}{l}\mathrm{CALCIUM}^{3} \\
(\mathrm{mmol})\end{array}$ & $\begin{array}{l}\text { CARBONATE }^{2} \\
\text { (Dissolved } \mathrm{CO}_{2} \text { ) }\end{array}$ & $\begin{array}{l}\text { SUGAR }^{3} \\
(\mathrm{gm})\end{array}$ & $\begin{array}{c}\text { DRIED }^{3} \\
\text { Wt. } \\
\text { (gm) }\end{array}$ \\
\hline Caffeinated & 12.60 & 3 & 3.78 & 5.4 & 0 & 3393 & 25 & 4.57 \\
\hline $\begin{array}{l}\text { Non - } \\
\text { Caffeinated }\end{array}$ & 0 & 5 & 0.008 & 5.8 & 0 & 3393 & 7.5 & 2.64 \\
\hline Milk & 0 & 6 & 15 & 6.9 & 15 & 0 & 24 & 6.5 \\
\hline $\begin{array}{l}\text { Deionized } \\
\text { Water }\end{array}$ & 0 & 0 & 0 & 7 & 0 & 0 & 0 & 0 \\
\hline
\end{tabular}

${ }^{1}$ Content per $500 \mathrm{ml}$ of all beverages.

${ }^{2}$ Obtained from PCSIR, Karachi.

${ }^{3}$ Determined by analysis in Biochemistry Laboratory of BMSI, JPMC - Karachi.

TABLE II:

COMPARISION OF URINARY CALCIUM ${ }^{1}$ BETWEEN PRE AND POST-DRINKS

\begin{tabular}{|c|c|c|c|c|}
\hline $\begin{array}{c}\text { URINARY } \\
\text { SAMPLES }\end{array}$ & $\begin{array}{c}\text { DEIONIZED } \\
\text { WATER } \\
(500 \mathrm{ml})\end{array}$ & $\begin{array}{c}\text { CAFFEINATED } \\
\text { DRINK } \\
(500 \mathrm{ml})\end{array}$ & $\begin{array}{c}\text { NON-CAFFENITED } \\
\text { DRINK }(500 \mathrm{ml})\end{array}$ & $\begin{array}{c}\text { MILK } \\
(500 \mathrm{ml})\end{array}$ \\
\cline { 2 - 5 } & $(\mathrm{n}=25)$ & $(\mathrm{n}=25)$ & $(\mathrm{n}=25)$ & $(\mathrm{n}=25)$ \\
\hline Pre-Beverage & 1.24 & 1.24 & 1.24 & 1.24 \\
& \pm 0.21 & \pm 0.21 & \pm 0.21 & \pm 0.21 \\
\hline Post- Beverage & $0.55^{\star \star \star}$ & $2.38^{\star \star \star}$ & $2.81^{\star \star}$ & $3.89^{\star \star \star}$ \\
(5 hours) & \pm 0.13 & \pm 0.35 & \pm 0.41 & \pm 0.54 \\
\hline
\end{tabular}

**P<0.01, $\quad$ ***P<0.001

${ }^{1}$ Values are expressed in mmol. 
FIGURE I:

PHYSIOLOGICAL PARAMETERS AND ANTHROPOMETRICAL MEASUREMENTS OF STUDY SUBJECTS

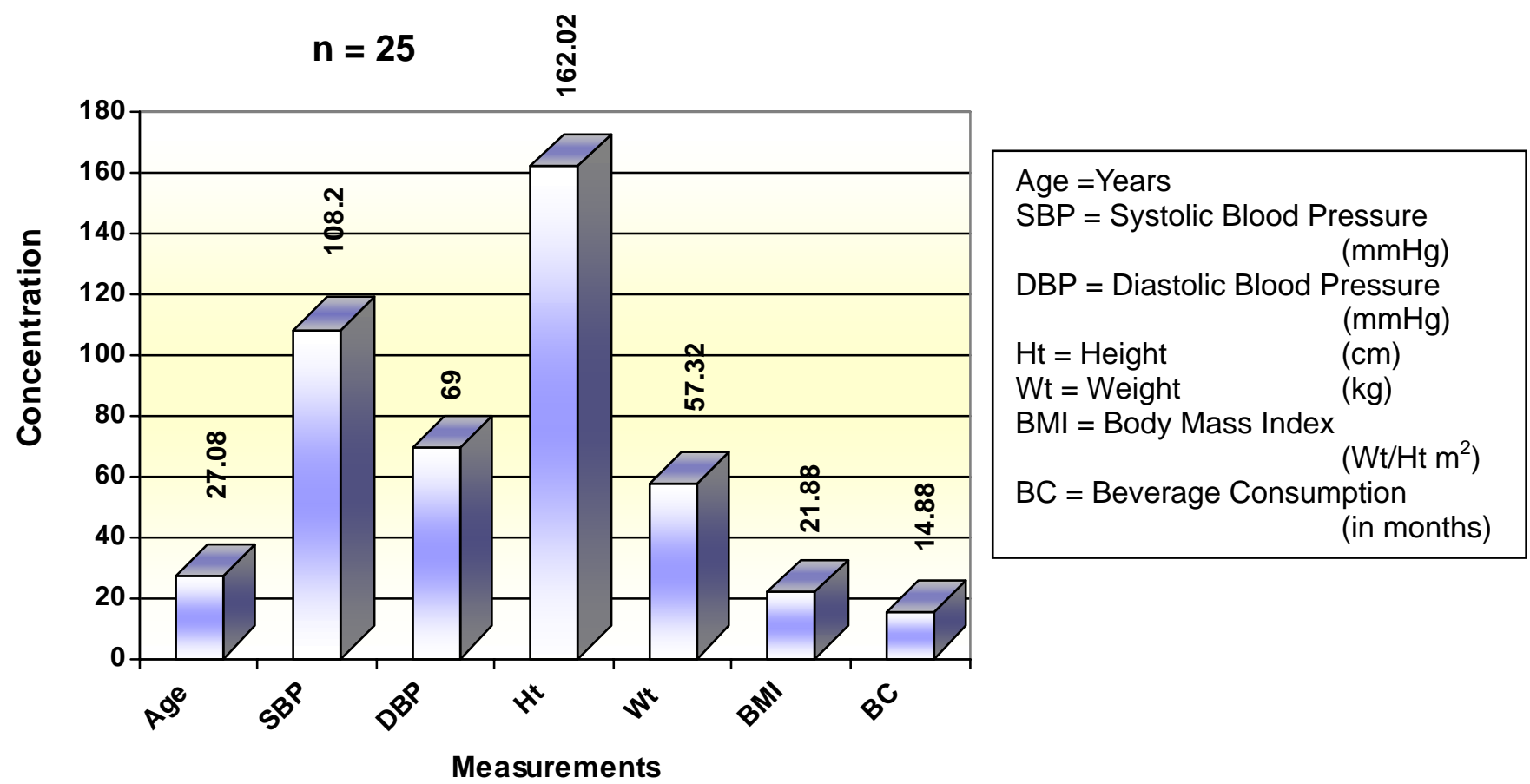

\section{DISCUSSION}

The previous studies carried out on same aspect were only on female subjects ${ }^{8-11}$, while we have seen the effects on male subjects. The characteristics and composition of beverages used were same as in previous studies though the amount of their ingredients was different. Diuretic effects of caffeine combined with increased urinary excretion suggests it as a risk factor for osteoporosis. ${ }^{12}$ The hypercalciuric effects are also confined to increased intake of refined carbohydrates ${ }^{13}$ and sodium chloride. ${ }^{14}$ The beverages, used in this study also contained sugar and sodium. The hypercalciuric effects in this study were not confined to the caffeinated beverages only but, were also seen with non-caffeinated beverages. In this study, we found the significant effect of caffeine on calcium excretion as compared to non-significant one in our previous study on females. ${ }^{8}$ It may be because of environmental or dietary patterns of our subjects and also due to difference that females lose more calcium in prebeverage fasting samples while males in postbeverage samples. This is supporting our hypothesis that the people who are habitual users of carbonated beverages show a low body mass index, which is towards the lean side and may have lost their bone mass early in life.

\section{CONCLUSION}

The results of present study suggest that the habitual and excessive use of carbonated beverages must be discouraged in order to avoid the negative calcium balance seen in carbonated beverage drinkers, which may cause bone resorptions and osteoporosis.

\section{REFERENCES}

1. Petriodou E, Karpathios T, Dessypriss N, et al. The role of dairy products and non-alcoholic beverages in bone fractures among school age children. Scan J Soc Med. 1997; 25: 119-125.

2. Wyshak G. Teen-aged girls, carbonated beverages consumption and bone fractures. Arch Pediatr Adolesc Med. 2000; 154: 610-13.

3. Milne DB, Neilson FH. The interaction between dietary fructose and magnesium adversely affects macro-mineral homeostasis in man. J Am Coll Nutr. 2000; 272: 1942.

4. Goulding A, Cannon R, Williams SM, et al. Bone 
mineral density in girls with fore-arm fractures. J Bone Miner Res. 1998; 13: 143-48.

5. Johnston CC Jr, Miller JZ, Slemenda CW. Calcium supplementation and increase in bone mineral density in children. N Engl J Med. 1992; 327: 82-87.

6. Kanders B, Dempster DW, Lindsay R. Interaction of calcium nutrition and physical activity on bone mass in young women. J Bone Miner Res. 1988; 2: $145-9$.

7. Barzel US. The skeleton as an ion exchange system; implications for the role of acid base imbalance in the genesis of osteoporosis. J Bone Miner Res. 1995;10: 1431-36.

8. Khan SA, Qureshi H, Karira KA, et al. The effects of soft drinks on normal healthy young women. Medical Channel. 2004; 10(4): 11-13.

9. Varley $H$. Calcium, Phosphorus and Phosphatases In: Practical Clinical Bioch- emistry, $2^{\text {nd }}$ edition. London, William HeinemannMedical Books Ltd. 1960; Pp. 354-55.

10. Varley H. Chloride, Sodium and Potasium In: Practical Clinical Biochemistry, $2^{\text {nd }}$ edition. London, William Heinemann-Medical Books Ltd. 1960; Pp. 387-91.

11. Heaney RP, Rafferty K. Carbonated beverages and urinary calcium excretion. Am J Clin Nutr. 2001;74: 343-47.

12. Arnand MJ. Caffeine, chemistry and physiological effect. In: Encyclopaedia of human nutrition. $3^{\text {rd }}$ edition, Water Institute Perrier Vittel, Villa Saint, France. 1998.

13. Thom JA, Morris JE, Bishop A, et al. The influence of refined carbohydrate on urinary calcium excretion. Br J Urol. 1978; 50:459-64.

14. Shortt C, Flynn A. Sodium-calcium interrelationship with specific reference to osteoporosis. Nutr Res Rev. 1990; 3:101-15.

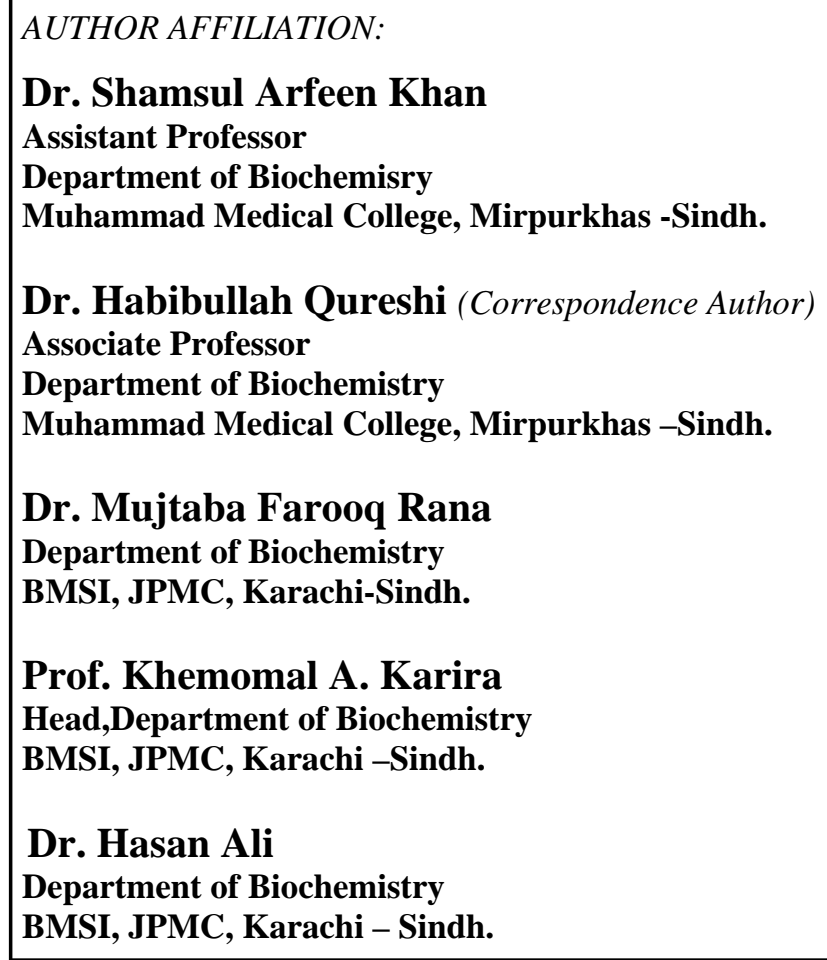

